\title{
Switching to Proximity Mobile Payment: Empirical Evidence from Korean Users
}

\author{
Hong-Lei Mu ${ }^{1}$ and Young-Chan Lee ${ }^{2, *}$
}

1 Department of International Business, Graduate School, Dongguk University, 38066, Gyeongju, Republic of Korea; muhonglei123@gmail.com

2 Department of Business Administration, College of Management and Economics, Dongguk University, 38066, Gyeongju, Republic of Korea; chanlee@dongguk.ac.kr

* Correspondence: chanlee@dongguk.ac.kr

\begin{abstract}
Individual users' payment behaviors have changed. The diffusion of mobile devices makes people suitable for proximity mobile payment (PMP) services without traditional payment. Existing mobile payment literature mainly focuses on users' adoption and continuous usage behavior. Nevertheless, switching behavior on payment received little attention, especially on why users switch from traditional payment to PMP. Thus, the objective of the current research is to investigate factors influencing users' traditional payment - PMP switching to comprehend how these factors shape users' switching intentions. We developed a traditional payment - PMP transition model based on the push-pull-mooring framework derived from migration theory. This research adopted a structural equation modeling analysis on 311 valid data. The findings indicate that a push factor drives users away from traditional payment in terms of dissatisfaction. The pull factors, including perceived substitutability and perceived usefulness, attract users to PMP. Furthermore, in terms of perceived technical compatibility, a positive mooring factor facilitates users' switching to PMP. The negative mooring factor, in terms of perceived risk, hinder users' switching intention. However, another pull factor - perceived ease of use, failed to influence switching intention significantly. This study found some distinctions between mobile payment switching and mobile payment adoption. These findings provide pivotal insights for mobile payment service providers.
\end{abstract}

Keywords: switching intention; proximity mobile payment; migration theory; push-pull-mooring framework; dissatisfaction

\section{Introduction}

The rapid development of mobile commerce establishes the fundamental demand for mobile payment (m-payment) services [1]. Advances in mobile technology have a significant impact on our daily life. Specifically, individual users' payment behaviors have changed. The diffusion of mobile devices makes people suitable for m-payment services without the need for traditional payment being placed in the physical wallet [2]. Dahlberg et al. [1] defined m-payment as payment for products, services, or bills via mobile devices under the condition of wireless and short-range communication technologies environment. Using m-payment, users can complete bill payments, account transfers, proximity or remote payments, disbursement, and even electronic currency services [2].

In contrast, the definition of traditional payment in this study is a payment for products, services, and bills via cash, credit cards, debit cards, or cheques. Compared with traditional payment, the primary superiority of m-payment is ubiquity [3]. In other words, an individual can complete the payment at any time and anywhere through mobile networks [3]. The convenience and transaction speed have guaranteed both merchants and individual users benefit from considerable time decrease, with obvious productivity gains [2].

M-payment is a complicated system. Researchers classified it into remote payment and proximity payment [4]. Remote payment refers to that remote payment servers is 
needed to be connected to conduct payment. It is suited for paying under the online transaction environment. Proximity payment refers to that users complete a transaction through mobile devices on the spot. It is suited for paying under the offline transaction environment. Proximity payment enables transaction data to be transmitted from the device of mobile network operator users to the point of sale (POS) terminal through shortrange communication technologies including near-field-communication (NFC), quick response (QR) code, barcode, and Bluetooth low energy [4]. According to [5], m-payment can also be split into payment for purchases versus payment for bills. The former competes with traditional payment. The latter provides access to account-based payments, for instance, direct debit assignment, online banking, or money transfer payments. In this paper, we focus on proximity mobile payment (PMP) and payments for purchases to correspond to the traditional payment used on the spot.

The widespread use of mobile devices has shifted the in-store transaction from traditional payment to PMP. The public health crisis triggered by COVID-19 has also accelerated the switching from traditional payment to PMP. Except for the impact of COVID-19 on nearly all aspects of daily life, the shifts towards e-commerce, digital payments (including contactless), instant payments, and cash displacement have all been significantly boosted in the first half of 2020 [6]. The number of PMP users was 0.95 billion all over the world in 2019 and is estimated to exceed 1 billion in 2020 [7]. In South Korea, approximately $37 \%$ of smartphone users had made a PMP transaction in the past six months [8], up from $31 \%$ in 2018 [9]. In terms of total transactions by volume, cash usage in South Korea has declined from $66 \%$ in 2010 to $34 \%$ in 2020 [6].

In the existing m-payment literature, researches mainly focus on users' adoption $[2,10,11]$, and continuous usage $[3,12,13]$. Nevertheless, switching behavior on payment received little attention, especially focusing on why users switch from traditional payment to PMP. The switching phase is different from the adoption phase. Generally, in the switching phase, users stop using or reduce the usage of the incumbent product or service significantly and potentially migrate to an alternative. It is not reasonable to discuss switching behavior from a continuous versus discontinuous perspective because when users switch, these two behaviors may exist in parallel [14]. Switching is usually considered post-adoption behavior [14], involving continuous usage and switching behavior. Individual users' switching is a complex decision. Users' decision to migrate from the incumbent (traditional payment, in this study) to an alternative service (PMP) involves the evaluations of both services [15]. Prior studies have consistently employed a set of variables to explain m-payment's adoption and continuous usage from a single perspective of m-payment. However, the reasons why some users terminate or reduce the use of the traditional payment and switch to PMP in a certain period are still unknown. Therefore, the objective of the current research is investigating influencing factors that affect migrants who switch from traditional payment to PMP to comprehend how these factors shape users' switching intentions. Research questions are then addressed: (1) What determinants affect migrants' willingness to switch from traditional payment to PMP? (2) How do the factors shape their switching intention?

To serve the research objective, this study develops a traditional payment - PMP transition model based on the push-pull-mooring (PPM) framework and migration theory. Migration theory was introduced to understand users' movement from an originating place to a destination in a particular time [16]. Theoretically, it emphasizes the need to look beyond a single product or service perspective when conducting a study. The findings could help further to understand the implications of m-payment beyond this optimistic situation. Practically, a comprehensive understanding of switching is necessary to notify m-payment service providers on users' attitudes towards traditional payment and PMP and optimize strategies for making the business more successful. 


\section{Theoretical Background}

\subsection{Switching Research}

Migration researchers consistently argue that the migrate or switch should have some permanence or a particular time to distinguish it from spatial mobile (such as business trips or holidays). However, the particular time for a move to be considered switching is hard to define [17]. Switching should be further classified as complete switching and partial switching [15]. Complete switching means the abandonment of an incumbent product or service [18]. Partial switching refers to that individuals use an alternative product or service without altogether terminating the old one [19]. [14] argue that though the term switching may indicate completely abandon the usage of the incumbent product or service, concurrent usage of both incumbent and alternative products or services is often possible, and sometimes it is necessary. Accordingly, we defined switching intention as users' willingness to switch to PMP with or without completely terminating traditional payment in a certain period [19].

Switching has been examined in personal technology products, social networking sites, offline and online services, healthcare services, and mobile services. Table 1 gives factors of switching and specific context. Through the table, three key patterns can be concluded. First, users' switching intention is relevant to their perceptions towards the incumbent product or service (push factor), such as dissatisfaction with its use; expectations of the alternative product or service (pull factor), such as alternative attractiveness. Second, security and privacy issues related to innovation may also influence switching. Third, factors influencing switching differ across research contexts. This study seeks to examine users' traditional payment - PMP transition using PPM framework.

\subsection{PPM Framework and the Migration Theory}

Migration theory [16] is derived from "Laws of Migration" [20]. Migration means a human being's movement between two places at a certain time. Migration may occur within the country (internal migration) or across countries (international migration) [16]. [21] classified migration into temporary versus permanent migration and voluntary versus involuntary migration. Temporary migrants return to the originating place after migrating. However, permanent migrants do not. Voluntary migrants determine when to switch without external constraints. Involuntary migrants have to migrate due to war and persecution constraints. For the case of this research, investigating factors influencing voluntary migration has theoretical and practical implications.

According to migration theory, switching is influenced by negative factors at the originating location, by positive factors at the destination [16], and by intervening factors that may facilitate or inhibit such switching [21]. A unifying PPM framework was built on the basis of migration theory by [17] for understanding individual users' service switching behavior. Push factors mean that negative effects at the originating location discourage people from staying. Pull factors mean that there are positive destination effects that act to attract people to the destination. Mooring factors are situational and personal effects that act to either promote or inhibit such switching behavior. Generally, push and pull effects are symmetrical [22]. The fundamental differences between push and pull effects depending on their properties or characteristics to the incumbent and alternative products or services [23]. The PPM framework derived from migration theory has been verified to be a dominant theoretical reference for switching research and has been applied to several contexts $[23,24]$. The advantages of considering both incumbent and alternative services and capturing distinct characteristics of the research context have made it a useful theory to understand users' switching behavior further. 
Table 1. Factors of switching.

\begin{tabular}{|c|c|c|c|c|}
\hline \multirow[b]{2}{*}{$\begin{array}{l}\text { Prior } \\
\text { study }\end{array}$} & \multirow[b]{2}{*}{$\begin{array}{l}\text { Specific } \\
\text { context }\end{array}$} & \multicolumn{3}{|c|}{ Factors of switching } \\
\hline & & $\begin{array}{l}\text { Incumbent prod- } \\
\text { uct or service } \\
\text { (push factor) }\end{array}$ & $\begin{array}{l}\text { Alternative prod- } \\
\text { uct or service (pull } \\
\text { factor) }\end{array}$ & Others \\
\hline$[15]$ & $\begin{array}{c}\text { Personal } \\
\text { information } \\
\text { technologies }\end{array}$ & Satisfaction $(+)$ & $\begin{array}{c}\text { Perceived relative } \\
\text { ease of use }(+) \\
\text { Perceived relative } \\
\text { security }(+) \\
\text { Relative advantage } \\
(+)\end{array}$ & $\begin{array}{c}\text { Subjective norm } \\
(-) \\
\text { Habit (-) } \\
\text { Perceived } \\
\text { switching costs } \\
(-) \\
\end{array}$ \\
\hline$[51]$ & $\begin{array}{c}\text { Social } \\
\text { networking } \\
\text { sites }\end{array}$ & $\begin{array}{l}\text { Weak connection } \\
\qquad(+) \\
\text { Writing anxiety }(+)\end{array}$ & $\begin{array}{c}\text { Enjoyment }(+) \\
\text { Relative usefulness } \\
\qquad(+) \\
\text { Relative ease of use } \\
(+)\end{array}$ & $\begin{array}{c}\text { Past experience } \\
(-) \\
\text { Switching cost } \\
(-)\end{array}$ \\
\hline$[78]$ & $\begin{array}{c}\text { PC to } \\
\text { mobile } \\
\text { shopping }\end{array}$ & Inconvenience $(+)$ & $\begin{array}{l}\text { Peer influence }(+) \\
\text { Alternative } \\
\text { attractiveness }(+)\end{array}$ & $\begin{array}{l}\text { Low security } \\
\text { and privacy (-) } \\
\text { Low trust (-) } \\
\text { High switching } \\
\text { cost (-) }\end{array}$ \\
\hline$[76]$ & $\begin{array}{c}\text { Social } \\
\text { networking } \\
\text { sites }\end{array}$ & $\begin{array}{c}\text { Regret }(+) \\
\text { Dissatisfaction }(+)\end{array}$ & $\begin{array}{c}\text { Alternative } \\
\text { attractiveness }(+)\end{array}$ & $\begin{array}{l}\text { Switching cost } \\
(-)\end{array}$ \\
\hline$[24]$ & $\begin{array}{c}\text { Cloud } \\
\text { computing }\end{array}$ & $\begin{array}{c}\text { Dissatisfaction } \\
\text { with client IT (+) }\end{array}$ & $\begin{array}{c}\text { Relative usefulness } \\
\qquad(+) \\
\text { Expected } \\
\text { omnipresence }(+)\end{array}$ & $\begin{array}{c}\text { Switching cost } \\
(-) \\
\text { Security } \\
\text { concerns (-) }\end{array}$ \\
\hline$[79]$ & $\begin{array}{l}\text { Technology } \\
\text { product }\end{array}$ & $\begin{array}{l}\text { Disconfirmation } \\
\qquad(+) \\
\text { Low satisfaction } \\
(+)\end{array}$ & $\begin{array}{l}\text { Relative advantage } \\
\qquad(+)\end{array}$ & $\begin{array}{c}\text { Inertia (-) } \\
\text { Switching cost } \\
(-) \\
\text { Network effect } \\
(-)\end{array}$ \\
\hline$[72]$ & $\begin{array}{c}\text { Healthcare } \\
\text { service }\end{array}$ & $\begin{array}{l}\text { Low satisfaction } \\
\qquad(+) \\
\text { Low commitment } \\
(+)\end{array}$ & $\begin{array}{c}\text { Ubiquitous care }(+) \\
\text { Responsiveness }(+) \\
\text { Personalized care } \\
(+)\end{array}$ & $\begin{array}{c}\text { Low } \\
\text { government } \\
\text { support (-) } \\
\text { Low trust (-) } \\
\text { High switching } \\
\text { cost (-) } \\
\text { Low privacy } \\
\text { and security (-) }\end{array}$ \\
\hline$[77]$ & $\begin{array}{c}\text { Mobile } \\
\text { instant } \\
\text { messaging }\end{array}$ & $\begin{array}{c}\text { Dissatisfaction }(+) \\
\text { Fatigue }(+)\end{array}$ & $\begin{array}{c}\text { Alternative } \\
\text { attractive }(+) \\
\text { Subjective norm }(+)\end{array}$ & $\begin{array}{l}\text { Inertia (affective } \\
\text { commitment, } \\
\text { switching cost, } \\
\text { and habit) (-) }\end{array}$ \\
\hline$[18]$ & $\begin{array}{c}\text { Cloud } \\
\text { storage } \\
\text { services }\end{array}$ & Perceived risk $(+)$ & $\begin{array}{l}\text { Transfer trust }(+) \\
\text { Critical mass }(+)\end{array}$ & $\begin{array}{l}\text { Social norm }(+) \\
\text { Low switching } \\
\text { cost }(+)\end{array}$ \\
\hline
\end{tabular}

As [16] stated, specific factors that drive migration are hardly identified because there are countless factors to attract or hamper people. These factors are hardly understanding 
accurately by the social scientist or by the migrants themselves. Thus, [16] suggested researchers set forth a few important factors and note a large group's average reaction. [24] gave compliments to migration theory and described it as a 'theoretic bridge.' This bridge connects the post-adoption and IT adoption research together, rather than studying them separately in the literature. Hence, this study identifies essential factors from post-adoption and $\mathrm{m}$-payment adoption literature. In addition, perceived substitutability is also included as a primary antecedent in this study. Perceived substitutability is introduced in the mass communication area to explore whether a new medium can substitute for the old one [25]. Whenever a new media has appeared in the market, the new market coexists with the traditional market [26]. This is also holding true in the payment market. PMP market coexists with the traditional payment market. To understand how new product or service alters the use of the old one, the first step is to investigate whether users perceived the new one to be substitutable for the existing one [27].

\subsection{Mobile Payment Research}

Prior research on m-payment has applied heavily to innovation acceptance theories. For example, the Technology Acceptance Model (TAM) [28], the Theory of Reasoned Action (TRA) [29], the Diffusion of Innovations (DOI) model [30], and their extensions have been applied so far. TAM holds that individuals' attitude towards accepting an innovation is determined by perceived usefulness (PUF) and ease of use (PEU). TRA argues that individuals' subjective norms and attitudes towards innovation are the determinants of adoption intention. [30] incorporated five variables into DOI to explain individuals' innovation adoption intention, and among these five factors, complexity, compatibility, and relative advantage were significant to individual users' acceptance decisions. According to [31], complexity has similarities with PEU, relative advantage has similarities with PUF.

[32] added four additional constructs into TAM - social influence, perceived financial cost, perceived risk, and personal innovativeness - to examine mobile credit cards as another form of m-payment in Malaysia. The moderating role of gender was also investigated. [33] extended TAM with two additional variables - perceived compatibility and social norm to examine the factors influencing m-payment adoption in Nigeria. [34] established a TAM-based model and compared three innovative m-payment systems in Spain. [35] developed a m-payment research model based on TAM. They believed that individual users' m-payment adoption decision is more than just m-payment characteristics issue; it also depends on individuals' characteristics. Therefore, in their paper, they elaborated the influences of individual differences systematically for the first time.

[11] examined the research to determine the factors influencing $\mathrm{m}$-payment adoption using the valence framework and DOI. They found that compatibility exerted a stronger influence on adoption intention in the positive valence than a relative advantage. In the negative valences, perceived risk negatively influences adoption intention. They also compared the pre-adoption and post-adoption and found that the effects on adoption intention differ across different stages. [36] built a m-payment decision-making model based on the valence framework. Their research found that factor from DOI - compatibility exerted the largest impact on behavioral intention in the positive valences. In the negative valences, perceived risk was the most significant factor. [2] created a research model to explore users' m-payment adoption intention. Among nine drivers, compatibility exerted the most considerable influence on users' behavioral intentions.

Given the importance of post-adoption usage to innovation service providers' success, numerous studies have focused on determining the factors affecting continuous usage behavior. The expectation-confirmation model (ECM) was introduced to understand individuals' continuous or discontinuous usage intention of innovation by [37]. He found that satisfaction and PUF are the determinants of continuous usage. And satisfaction is affected by confirmation and PUF. ECM is widely employed in the mobile services context [38-40] and a m-payment context [13]. Nowadays, it has become a practical theory for post-adoption research [38,39]. 
Overall, the studies mentioned above have provided valuable insights on factors influencing individual users' m-payment acceptance and continuous usage. And we found that PUF, PEU, compatibility, and perceived risk are the most significant variables for $\mathrm{m}$ payment adoption. Based on migration theory, dissatisfaction, a primary factor in postadoption research, was selected as push factor. Pull factors include perceived substitutability, PUF, and PEU. Pull factors attract users to migrate to PMP. Lastly, mooring factors are perceived technical compatibility and perceived risk. These factors either facilitate or hinder users' switching intentions. This study also involves control variables: self-efficacy, gender, age, length of use, and occupation into the research model. Such an understanding is expected to enhance payment service providers' understanding of users' payment switching behavior, hence helping them boost their business.

\section{Hypotheses Development}

Figure 1 displays the research model. In migration theory [16], a factor may be counted as "+" by an individual and "-" by another individual (p. 50), indicating that push, pull, and mooring factors reflect users' attitude towards the incumbent product or service and the alternative product or service. TRA [29] concludes that attitude directly influences users' intentions. [17] also identified that push, pull, and mooring factors influence switching intention directly.

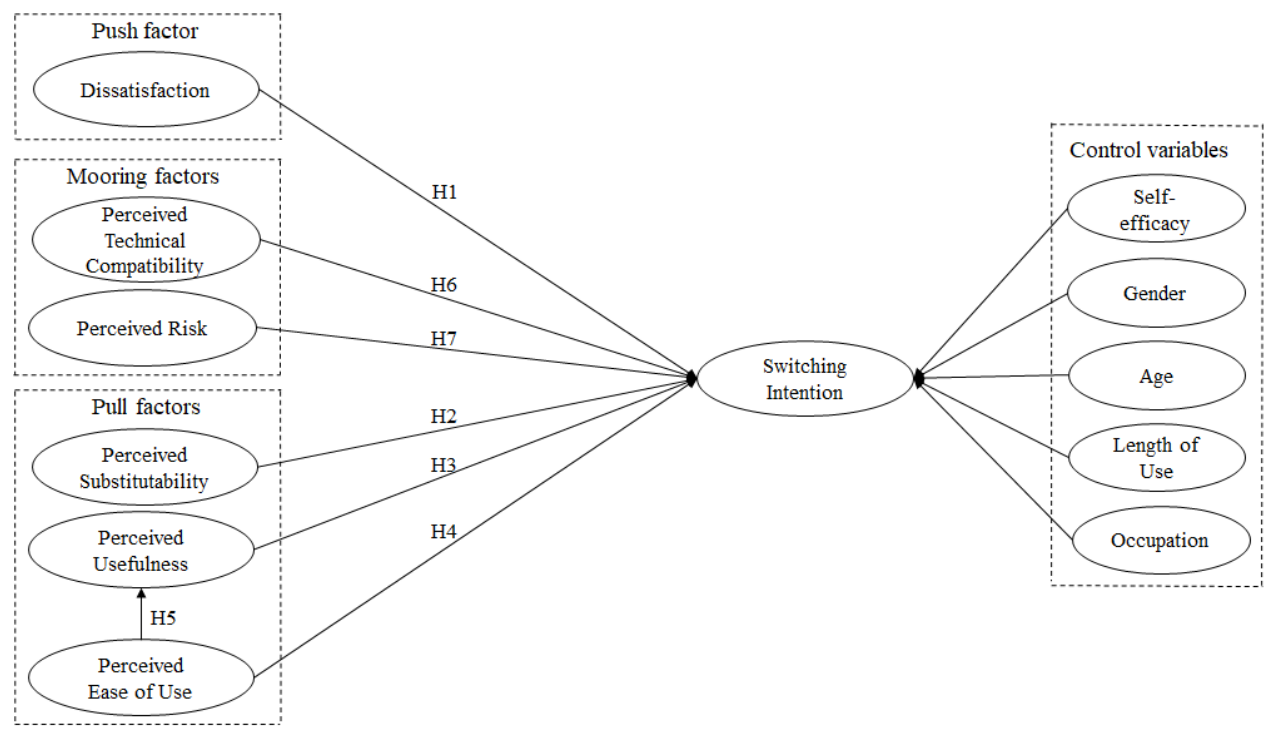

Figure 1. Research model.

\subsection{Push Factor}

Push factors are traditional payment factors that discourage an individual from using traditional payment [17]. In the post-adoption phase, the discontinuous intention of the incumbent product or service is primarily relevant to users' dissatisfaction with the product or service [37,41]. ECM also states that satisfied users would likely use the innovation continuously, and dissatisfied users would consider migrating to an alternative innovation [37]. The current research defined dissatisfaction as an effect reflecting users' overall evaluation about their prior experience using the traditional payment.

Though ECM and dissatisfaction are mainly adopted in IT context, following a similar vein, we can infer that if users are dissatisfied with their prior experience using traditional payment, they may consider switching to PMP. Traditional payment has several constraints. According to [42], cash exists numerous microorganisms, including bacteria, viruses, parasites, etc. It is the primary approach to disseminate disease. [6] reported that COVID-19 has accelerated the displacement of cash payment and estimated that COVID19 would likely lead to a further decline in cash usage. Second, there is a security problem for cash, such as robbery, cheating issues. Third, the social cost of cash is too much because 
the average lifetime is short, and the administrative expense is high. Users need to make a change for cash transactions, and it costs much more time than PMP transactions. People who require real-time action and require prompt transactions [43] will not be satisfied with cash payment. Additionally, users need to carry all the cards with them if any card could be useful, and they need to manage the security of the cards.

The constraints of traditional payment lead to low confirmation among users, which causes dissatisfaction and discontinuous use intention. Users are likely to be dissatisfied and switch to PMP service if they have a poor experience using traditional payment. Additionally, in both service-related and IS-related switching research, this construct has been well documented as a significant factor to push people away $[14,44]$. Therefore:

Hypothesis 1. Dissatisfaction with traditional payment usage positively influences switching intention.

\subsection{Pull Factors}

Pull effects refer to PMP effects that attract an individual to use PMP [17]. Perceived substitutability means that users adopt a new medium over a traditional one. The new medium has a functional similarity and functional desirability over the traditional one to satisfy their specific needs $[45,46]$. Functional desirability is associated with characteristics that emphasize desirable features and premium content [25]. Though widely used in the mass communication context, perceived substitutability is believed to offer valuable insights into the payment context because of users' congruence facing e-commerce systems [47] and mobile commerce systems. Perceived substitutability is thus defined as to what extent users perceived that PMP is more functionally desirable than traditional payment in satisfying their specific needs [25].

PMP has the fundamental functional similarity with traditional payment in that both enable users to make an in-store transaction. PMP, in many cases, has desirable functions or features over traditional payment. PMP's fast speed and convenient usage allow users to save transaction time [48]. Users can access the PMP platform at any time and anywhere [3]. Some functions may gratify users' economic benefit needs. For instance, Kakaopay from KakaoTalk, a leader in the mobile instant messaging application market in Korea, enables users to scan barcodes and earn points from various brands. Samsung Pay offers a cashback feature, including bonus Samsung account points and vouchers with many participating retailers.

Prior studies have adopted perceived substitutability as the primary driver of switching intention. [49] examined the antecedents of individuals' switching intentions between in-store membership cards and mobile branded apps. The results indicated that perceived substitutability is a vital determinant of switching intention. Potential adopters are more likely to perceive a superiority of innovation if they obtain the efficiency, convenience, economic benefits, or even image enhancement benefits [30]. An individual's willingness to substitute is positively correlated with the benefits they expect to receive from the alternative services.

How to distinguish push and pull effects depends on their properties and pertinence to the incumbent or alternative product or service $[22,23]$. Perceived substitutability emphasis on the functional desirability of PMP over traditional payment. Hence, this construct is a positive pull factor to attract users to use PMP. Notably, the current research aims not to investigate whether PMP can substitute for traditional payment. Instead, the aim is to identify the extent to which users perceive substitutability between two payment services. This may provide insights into the importance of PMP functions in gratifying users' needs:

Hypothesis 2. Perceived substitutability positively influences switching intention. 
By examining m-payment adoption research, the most consistent predictors of $\mathrm{m}$ payment adoption are PUF and PEU [11,32,34]. PUF means the degree to which prospective users believe that their transaction performance would be improved by using PMP [28]. Users are likely to adopt PMP because they realize the benefits and conveniences provided by the services. Such benefits including combining bank cards and loyalty cards with mobile devices, shopping without physical wallets, tracking expenses, and increasing their transaction convenience. PEU means the degree to which prospective users believe that PMP is easy to use [28]. Under individual users' context, the willingness to accept an innovation is highly correlated to its complexity [50]. Specifically, the more complex, the lower willingness to adopt the innovation. The characteristic of ease to use can dramatically increase users' switching intention to the innovation. Both constructs have been verified as effective pull factors on migrants' switching context [15,24,51]. In addition, PEU has been proved to affect PUF significantly [52-54]. Accordingly:

Hypothesis 3. PUF positively influences switching intention.

Hypothesis 4. PEU positively influences switching intention

Hypothesis 5. PEU positively influences PUF.

\subsection{Mooring Factors}

Mooring effects are situational and personal effects that may promote or hinder individuals' switching intention to PMP [55]. M-payment adoption literature has confirmed perceived compatibility and perceived risk as important determinants of users' adoption intention.

The operationalization of compatibility has a much broader connotation, and the construct is inconsistent across studies [56]. Table 2 presents the dimensions, conceptual and operational definitions of compatibility. Researchers consistently capture two motivations through different dimensions and operations: intrinsic motivations by compatibility [57] and extrinsic motivations by compatibility [56]. Intrinsic motivations are derived from compatibility with users' value and style, while extrinsic motivations are derived from compatibility with existing work practices, prior experience, or optimal functionalities. According to Table 2, there are perceived lifestyle compatibility and perceived technical compatibility dimensions [58]. However, prior studies have focused on compatibility from a lifestyle perspective in the mobile services context $[2,11,59]$, while they have overlooked mainly perceived technical compatibility. Perceived technical compatibility refers to the degree of compatibility of the PMP with users' mobile devices, apps, and operating systems (OSs) [58].

To complete a satisfactory transaction, users' mobile devices, OSs, and apps should be integrated with PMP services. For example, NFC payment service providers need to ensure users' transaction information be sent out through NFC technology to the server, bank card company, POS machine, and value-added network. Code scanning service providers need to ensure the payment apps be available to users' mobile device OSs. Simultaneously, they need to make sure there are no compatibility problems, such as problems in the payment app crash or halt when using, problems in jumping between payment app and other apps. The more comfortable an innovation integrates with existing innovation, the greater the possibilities of recognizing the benefits [60]. In addition, [58] examined antecedents that could influence migrants' intention to migrate to mobile personal cloud storage services. Their research indicated that perceived technical compatibility serves as a significant factor in switching intention.

Perceived technical compatibility is regarded as an extrinsic motivation by compatibility in the current study. It refers to PMP service providers' ability to ensure the compatibility of their services. Service providers' abilities are usually considered as a situational factor [24]. Hence, this construct should represent a positive mooring factor to facilitate users to switch to PMP:

Hypothesis 6. Perceived technical compatibility positively influences switching intention. 
Table 2. Summary of prior studies on compatibility: dimensions, conceptual and operational definitions.

\begin{tabular}{|c|c|c|c|}
\hline $\begin{array}{l}\text { Prior } \\
\text { study }\end{array}$ & $\begin{array}{c}\text { Research } \\
\text { context }\end{array}$ & Dimensions & $\begin{array}{c}\text { Conceptual and operational } \\
\text { definitions }\end{array}$ \\
\hline \multirow{2}{*}{ [80] } & \multirow{2}{*}{$\begin{array}{l}\text { Technology } \\
\text { product }\end{array}$} & $\begin{array}{l}\text { Normative or } \\
\text { cognitive } \\
\text { compatibility }\end{array}$ & Compatibility with what people feel. \\
\hline & & $\begin{array}{l}\text { Practical or } \\
\text { operation } \\
\text { compatibility }\end{array}$ & Compatibility with what people do. \\
\hline \multirow{2}{*}{ [81] } & \multirow{2}{*}{ Telecommuting } & $\begin{array}{c}\text { Practical } \\
\text { compatibility }\end{array}$ & $\begin{array}{l}\text { Climate for the innovation's } \\
\text { implementation. }\end{array}$ \\
\hline & & $\begin{array}{c}\text { Value } \\
\text { compatibility }\end{array}$ & $\begin{array}{l}\text { Compatibility with people's values at } \\
\text { the organizational level. }\end{array}$ \\
\hline \multirow{4}{*}{ [56] } & \multirow{4}{*}{$\begin{array}{l}\text { Customer } \\
\text { relationship } \\
\text { management } \\
\text { system in the } \\
\text { context of a } \\
\text { large bank }\end{array}$} & $\begin{array}{l}\text { Compatibility } \\
\text { with preferred } \\
\text { work style }\end{array}$ & $\begin{array}{l}\text { The possibility provided by the } \\
\text { technology of being consistent with an } \\
\text { individual's desired work style. }\end{array}$ \\
\hline & & $\begin{array}{l}\text { Compatibility } \\
\text { with values }\end{array}$ & $\begin{array}{l}\text { The compatibility between the } \\
\text { possibilities offered by the technology } \\
\text { and an individual's dominant value } \\
\text { system. }\end{array}$ \\
\hline & & $\begin{array}{c}\text { Compatibility } \\
\text { with existing } \\
\text { work practices }\end{array}$ & $\begin{array}{l}\text { The degree of change a person may } \\
\text { experience when adopting a new } \\
\text { technology. }\end{array}$ \\
\hline & & $\begin{array}{l}\text { Compatibility } \\
\text { with prior } \\
\text { experience }\end{array}$ & $\begin{array}{l}\text { The degree of compatibility between } \\
\text { the technology and the diversity of } \\
\text { individuals' past encounters with } \\
\text { technology. }\end{array}$ \\
\hline \multirow[b]{2}{*}{ [82] } & \multirow{2}{*}{$\begin{array}{l}\text { Electronic } \\
\text { products }\end{array}$} & $\begin{array}{c}\text { Lifestyle } \\
\text { compatibility }\end{array}$ & $\begin{array}{l}\text { An innovation's compatibility in } \\
\text { terms of situational properties. }\end{array}$ \\
\hline & & $\begin{array}{l}\text { Infrastructural } \\
\text { compatibility }\end{array}$ & $\begin{array}{l}\text { An innovation's compatibility with } \\
\text { other products in terms of its } \\
\text { connectivity or shared infrastructure. }\end{array}$ \\
\hline \multirow{2}{*}{ [58] } & \multirow{2}{*}{$\begin{array}{l}\text { Mobile personal } \\
\text { cloud storage } \\
\text { services }\end{array}$} & $\begin{array}{l}\text { Perceived lifestyle } \\
\text { compatibility }\end{array}$ & $\begin{array}{l}\text { The degree to which adopting an } \\
\text { innovation to be compatible with } \\
\text { one's lifestyle. }\end{array}$ \\
\hline & & $\begin{array}{c}\text { Perceived } \\
\text { technical } \\
\text { compatibility }\end{array}$ & $\begin{array}{l}\text { The degree of compatibility of the } \\
\text { innovation with users' mobile devices, } \\
\text { apps, and operational systems (OSs). }\end{array}$ \\
\hline
\end{tabular}

Perceived risk theory [61] holds that users may generate risk beliefs about innovation-based service when using it. Risk beliefs about m-payment services include loss of funds belief and personal information leakage belief [62]. Users' risk beliefs towards mpayment are expected to be high because they cannot evaluate the services due to the intangibility features of the service [63]. Therefore, perceived risk is considered as the most considerable inhibitor for using this service [64]. Perceived risk means the degree of possible loss of money and private information when pursuing a satisfying outcome of using PMP [61].

Personal information leakage includes name, phone number, home address, and resident registration number. And it also involves detailed information, including income, payment account, car ownership, and financial information (e.g., payment data, credit rating) [65]. Both financial and privacy risks can occur either by payment POS or outsourcing 
companies, hacking, and internal employees [65]. Privacy issues are significant barriers for Korean users to accept m-payment services [65]. If the service providers cannot operate a secure system and protect users' financial and private information from leaking, users' intention to switch to PMP will decrease.

Notably, perceived risk in this study emphasizes m-payment service providers' ability to decrease users' risk concerns rather than m-payment characteristics. Similarly, service providers' abilities are usually regarded as situational factors [24]. Thus, this construct is a negative mooring factor that prevents users from switching to PMP:

Hypothesis 7. Perceived risk negatively influences switching intention.

\subsection{Control Variable: Self-efficacy, Gender, Age, Length of Use, and Occupation}

In the innovation literature, other predictors may also influence users' intentions. For example, perceived behavioral control is proved to impact users' intention [66]. It reflects the degree to which perceived ease or complexity to perform a target behavior. Perceived behavioral control includes internal control and external control [67]. The former is alternatively regarded as self-efficacy, meaning how well a person can perform a series of actions required to manage prospective situations [68]. [67] stated that internal control mainly influences intention. Demographic variables, including gender, age, length of use, and occupation that may affect switching intention, were also involved in the research model.

\section{Research Methodology}

\subsection{Measurement Development}

To acquire feedback on the instruments' validity and reliability, a pilot test including fifty-four university students who were invited through the Internet was conducted. According to their feedback on the instruments, some instruments were modified. For instance, one of the switching intention instrument was changed from "I am willing to switch from traditional payment to PMP in a physical store in the near future" to "rate your possibility to switch from traditional payment to proximity mobile payment in a physical store in the near future." Four items were eliminated after the pilot test because of low factor loadings. Finally, 32 items were retained and were measured using sevenpoint Likert scales, with 1 representing strongly disagree and 7 representing strongly agree. All measurement instruments for the constructs were adopted and adapted from prior studies. The measurement items and sources were shown in Appendix A in detail.

\subsection{Data Collection and Descriptive Analysis}

The analysis unit of the current study was individual users who have used traditional payment and PMP in a physical store. To restrict the data to analysis respondents, only people with PMP usage experience in the past six months in a physical store were selected. An online questionnaire was distributed to universities in Gyeongsangbuk-do, Korea, in April 2020. 372 people participated in the survey, and 61 were removed due to: (1) the respondents have no experience using PMP or have no experience using PMP in the past six months; (2) the answers given by the respondents were all the same; (3) some of them are foreigners. These were resulting in 311 usable questionnaires. The descriptive statistics of the respondents were presented in Table $3.59 .2 \%$ are male, and approximately $89 \%$ had less than three years experience using PMP.

Following [69,70], this study compares the first $25 \%$ and the final $25 \%$ responses and valid data and invalid data to detect non-response bias. Appendix B shows the comparison t-test results. T-test verified that non-response bias was not a threat to our data.

Table 3. Descriptive statistics of respondents.

\begin{tabular}{cccc}
\hline & Category & Count & $\%$ \\
\hline Gender & Male & 184 & $59.2 \%$ \\
\hline
\end{tabular}




\begin{tabular}{|c|c|c|c|}
\hline & Female & 127 & $40.8 \%$ \\
\hline Age & $\begin{array}{l}\text { Open-ended } \\
\text { question }\end{array}$ & \multicolumn{2}{|c|}{$19-57$} \\
\hline $\begin{array}{l}\text { Do you have experience engaging in the } \\
\text { proximity mobile payment activities in } \\
\text { the past six months? For instance, making } \\
\text { a transaction in a physical store, or } \\
\text { download the proximity mobile payment } \\
\text { app and learn how to use it. }\end{array}$ & Yes & 311 & $100 \%$ \\
\hline \multirow{5}{*}{ Length of use } & $<6$ months & 89 & $28.6 \%$ \\
\hline & $\begin{array}{c}6 \text { months - } 1 \\
\text { year }\end{array}$ & 51 & $16.4 \%$ \\
\hline & 1 year -3 years & 137 & $44.1 \%$ \\
\hline & $\begin{array}{c}3 \text { years - } 6 \\
\text { years }\end{array}$ & 32 & $10.3 \%$ \\
\hline & $>6$ years & 2 & $0.6 \%$ \\
\hline \multirow{5}{*}{ Occupation } & $\begin{array}{c}<\text { High school } \\
\text { student }\end{array}$ & 0 & $0 \%$ \\
\hline & $\begin{array}{c}\text { Undergraduate } \\
\text { student }\end{array}$ & 284 & $91.3 \%$ \\
\hline & $\begin{array}{l}\text { Graduate or } \\
\text { Ph.D. student }\end{array}$ & 5 & $1.6 \%$ \\
\hline & Employee & 10 & $3.2 \%$ \\
\hline & Others & 12 & $3.9 \%$ \\
\hline \multirow{4}{*}{ Nationality } & South Korea & 311 & $100 \%$ \\
\hline & China & 0 & $0 \%$ \\
\hline & Vietnam & 0 & $0 \%$ \\
\hline & Others & 0 & $0 \%$ \\
\hline
\end{tabular}

\section{Results}

\subsection{Measurement Model}

AMOS 22.0 was adopted for data analysis. Before analyzing, measurement items for dissatisfaction and perceived substitutability were reversed. Exploratory factor analysis (EFA), whose goal is to guarantee high loadings on respective constructs and low loadings on cross-loadings, was conducted. Factor loadings higher than 0.50 were obtained, and they loaded on respective constructs. Significant components have eigenvalues over 1.0 were obtained.

Confirmatory factor analysis has proceeded. Normalized chi-square (X2/df) was 1.696 , incremental fit index (IFI) was 0.962, goodness of fit index (GFI) was 0.878 , comparative fit index (CFI) was 0.961, normed fit index (NFI) was 0.911, root mean square error of approximation (RMSEA) was 0.047 . Each value was within the threshold, thus suggesting satisfactory values. A good convergent validity should satisfy three conditions: first, factor loadings should surpass 0.50; second, composite reliability (CR) should exceed 0.70; third, average variance extracted (AVE) should surpass 0.50 [71]. According to Table 4, all the three conditions had been statistically verified, and Cronbach's alpha exceeded 0.70 . Afterward, discriminant validity was tested (Table 5). The square root of AVEs was higher than the correlation coefficients of inter-construct, suggesting satisfactory discriminant validity. Since the survey of this research was collected from a single source and was used the self-report method, common method bias (CMB) may become a potential issue.

Table 4. Results of confirmatory factor analysis. 


\begin{tabular}{|c|c|c|c|c|}
\hline Measurements & Estimate & $\begin{array}{c}\text { Cronbach } \\
\text { alpha }\end{array}$ & C.R. & AVE \\
\hline DIS1 & 0.811 & \multirow{4}{*}{0.924} & \multirow{4}{*}{0.926} & \multirow{4}{*}{0.758} \\
\hline DIS2 & 0.859 & & & \\
\hline DIS3 & 0.905 & & & \\
\hline DIS4 & 0.905 & & & \\
\hline TCP1 & 0.817 & \multirow{3}{*}{0.881} & \multirow{3}{*}{0.885} & \multirow{3}{*}{0.720} \\
\hline TCP2 & 0.901 & & & \\
\hline TCP3 & 0.825 & & & \\
\hline PER1 & 0.696 & \multirow{6}{*}{0.886} & \multirow{6}{*}{0.870} & \multirow{6}{*}{0.535} \\
\hline PER2 & 0.721 & & & \\
\hline PER3 & 0.587 & & & \\
\hline PER4 & 0.558 & & & \\
\hline PER5 & 0.874 & & & \\
\hline PER6 & 0.888 & & & \\
\hline PSS1 & 0.805 & \multirow{3}{*}{0.825} & \multirow{3}{*}{0.828} & \multirow{3}{*}{0.616} \\
\hline PSS2 & 0.834 & & & \\
\hline PSS3 & 0.711 & & & \\
\hline PUF1 & 0.820 & \multirow{4}{*}{0.907} & \multirow{4}{*}{0.908} & \multirow{4}{*}{0.712} \\
\hline PUF2 & 0.886 & & & \\
\hline PUF3 & 0.851 & & & \\
\hline PUF4 & 0.817 & & & \\
\hline PEU1 & 0.864 & \multirow{4}{*}{0.925} & \multirow{4}{*}{0.925} & \multirow{4}{*}{0.755} \\
\hline PEU2 & 0.938 & & & \\
\hline PEU3 & 0.848 & & & \\
\hline PEU4 & 0.822 & & & \\
\hline SEF1 & 0.727 & \multirow{5}{*}{0.925} & \multirow{5}{*}{0.922} & \multirow{5}{*}{0.705} \\
\hline SEF2 & 0.827 & & & \\
\hline SEF3 & 0.884 & & & \\
\hline SEF4 & 0.871 & & & \\
\hline SEF5 & 0.879 & & & \\
\hline SWI1 & 0.842 & \multirow{3}{*}{0.929} & \multirow{3}{*}{0.932} & \multirow{3}{*}{0.822} \\
\hline SWI2 & 0.941 & & & \\
\hline SWI3 & 0.933 & & & \\
\hline
\end{tabular}

Note: DIS = Dissatisfaction; TCP = Perceived technical compatibility; PER = Perceived risk; PSS = Perceived substitutability; PUF = Perceived usefulness; PEU = Perceived ease of use; $\mathrm{SEF}=$ Self-efficacy; SWI $=$ Switching intention .

Table 5. Inter-construct correlation coefficients.

\begin{tabular}{ccccccccc}
\hline & DIS & TCP & PER & PSS & PUF & PEU & SEF & SWI \\
\hline DIS & $\mathbf{0 . 8 7 0}$ & & & & & & & \\
\hline TCP & -0.012 & $\mathbf{0 . 8 4 9}$ & & & & & & \\
\hline PER & $-0.155^{* *}$ & $-0.221^{* *}$ & $\mathbf{0 . 7 3 1}$ & & & & & \\
\hline PSS & $-0.265^{* *}$ & $0.140^{*}$ & -0.106 & $\mathbf{0 . 7 8 5}$ & & & & \\
\hline PUF & 0.023 & $0.382^{* *}$ & $-0.238^{* *}$ & $0.194^{* *}$ & $\mathbf{0 . 8 4 4}$ & & & \\
\hline PEU & -0.043 & $0.476^{* *}$ & $-0.186^{* *}$ & $0.199^{* *}$ & $0.543^{* *}$ & $\mathbf{0 . 8 6 9}$ & & \\
\hline SEF & 0.004 & $0.393^{* *}$ & $-0.276^{* *}$ & $0.309^{* *}$ & $0.542^{* *}$ & $0.648^{* *}$ & $\mathbf{0 . 8 4 0}$ & \\
\hline SWI & $0.180^{* *}$ & $0.415^{* *}$ & $-0.365^{* *}$ & $0.222^{* *}$ & $0.595^{* *}$ & $0.476^{* *}$ & $0.530^{* *}$ & $\mathbf{0 . 9 0 7}$ \\
\hline
\end{tabular}


Note: Square root of AVE is presented in bold. DIS $=$ Dissatisfaction; TCP $=$ Perceived technical compatibility; PER = Perceived risk; PSS = Perceived substitutability; PUF = Perceived usefulness; PEU = Perceived ease of use; SEF = Self-efficacy; SWI = Switching intention.

Three methods were adopted to assess whether $\mathrm{CMB}$ significantly attributed to the variance among the survey items. Appendix $C$ and D presented the results in detail.

\subsection{Structural Assessment}

After establishing an eligible measurement model, structural model was assessed. The $X^{2} / d f$ was 1.714 . The structural model (CFI was 0.952 , IFI was 0.953 , NFI was 0.894 , GFI was 0.868 , RMSEA was 0.048) fit well with the data. Figure 2 summarizes the research model. Except for H4, all other 6 of the hypotheses were supported. Nevertheless, PEU indirectly influence switching intention significantly $(0.294, \mathrm{p}<0.01)$ (Table 6). The control variable of self-efficacy also influenced switching intention significantly. Other control variables failed to impact switching intention significantly. Main determinants and control variables jointly explained $52.5 \%$ of the variance of switching intention. PEU explained $36 \%$ of the variance of PUF.

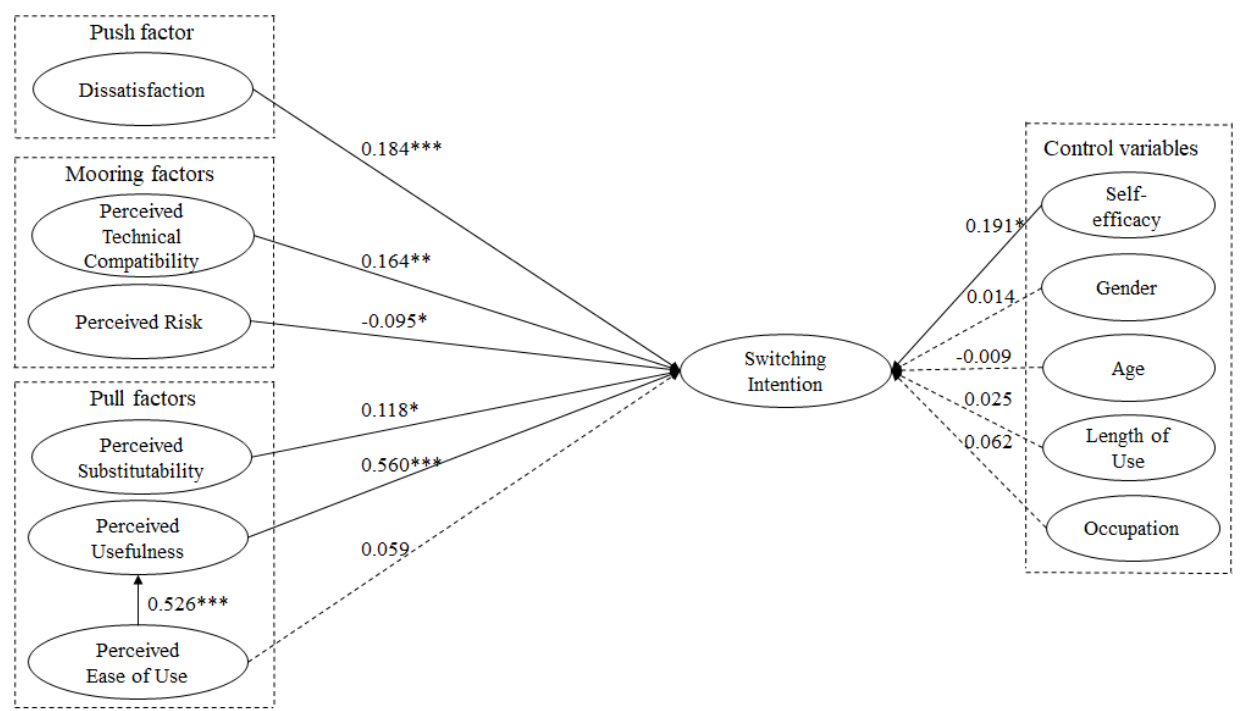

Figure 2. Model tests results.

${ }^{*} \mathrm{p}<0.05 ;{ }^{* *} \mathrm{p}<0.01 ;{ }^{* * *} \mathrm{p}<0.001$

Table 6. Direct and indirect effects of PEU on switching intention.

\begin{tabular}{lccc}
\hline & Direct effect & Indirect effect & Total effect \\
\hline $\begin{array}{l}\text { Perceived ease of use } \rightarrow \text { Perceived } \\
\text { usefulness } \rightarrow \text { Switching intention }\end{array}$ & 0.059 & $0.294^{* *}$ & $0.353^{* *}$ \\
\hline
\end{tabular}

Note: ${ }^{* *} \mathrm{p}<0.01$.

\section{Conclusions and Discussion}

\subsection{Research Findings}

The current research investigates factors influencing users' traditional payment PMP switching to comprehend how these factors shape users' switching intentions. Most hypotheses were supported. First, dissatisfaction with traditional payment, adopted as main push factor, positively affected switching intention. Traditional payment, such as cash and bank cards, has several constraints, and it costs much more time than PMP. These constraints may lead users to decrease the usage of traditional payment and potentially 
adopt PMP frequently. This finding is consistent with [72], who demonstrated that dissatisfaction is a determinant of switching intention.

Second, the pull factors, in terms of perceived substitutability, and PUF, positively affected switching intention. Specifically, PUF had the most substantial impact (0.560), followed by perceived substitutability. Users tend to adopt PMP if they believe the service is useful, convenient to use, and quick to complete a transaction. This finding agrees with [24], who revealed that PUF created end-user's intention to switch to cloud computing. PMP's desirable functions make users perceive that PMP is a substitution service of traditional payment under an offline environment, thus enhancing their switching intention. Prior study also found that substitutability between branded cards and mobile applications can increase consumers' migration intention to mobile applications. Out of our expectation, PEU had no significant impact on switching intention, but it was associated with PUF. The findings for the impact of PEU on m-payment adoption have been mixed $[2,35,73]$. The findings about PEU indicate that the degree of effort free in using PMP can result in higher perceptions of usefulness in performing payment tasks. Still, it may not enhance the intention to switch to PMP.

Third, in terms of perceived technical compatibility, the mooring factors positively affected switching intention, whereas perceived risk negatively affected switching intention. The result of perceived technical compatibility is in line with [58], who revealed that perceived technical compatibility is an important factor of migrants' mobile cloud storage migration intention. Additionally, users with strong concern about personal information and monetary loss are reluctant to switch to PMP. This result is in accordance with [74], who claimed that a vital barrier for users to accept m-payment is perceived risk.

\subsection{Theoretical Implications}

The current research advances the knowledge of switching intention and m-payment. First, different from prior studies, this study identifies and empirically examines influencing factors of users' traditional payment - PMP transition from a switching perspective. Prior studies on m-payment have consistently investigated users' adoption and continuous usage. However, switching behavior on payment received little attention. Users' switching decision involves the evaluations of incumbent services as well as alternative services. This study reveals that users' switching intention is correlated with alternative services (PMP) and determined by the factor of incumbent services (traditional payment). This study emphasizes the need to look beyond a single service perspective when conducting a study.

Second, this study extends the existing m-payment research by applying the migration theory. Migration theory is like a 'theoretic bridge.' This bridge links post-adoption and IT adoption research together, rather than studying them separately in the literature. This study integrated constructs from post-adoption with constructs from m-payment adoption into one proposed model based on migration theory.

Third, this research enriches the knowledge of the relationship between TAM, DOI theories, and switching intention. Although TAM and DOI have been adopted in users' acceptance of specific innovation extensively, the roles in switching behavior have rarely been investigated. Specifically, this study found some distinctions between $\mathrm{m}$-payment switching and m-payment adoption. PEU, traditionally a dominant factor in m-payment adoption research, was not significant to m-payment switching. However, PUF and dissatisfaction with traditional payment are more influential. These findings support the notion that regardless of the strong effect on initial adoption, ease of use cannot consistently explain post-adoption [37]. Thus, these results provide additional insights to mobile commerce research, especially to m-payment research.

\subsection{Managerial Implications}

The current study also makes important contributions for PMP service providers. First, the results found that when users are dissatisfied with traditional payment, their intentions of switching from traditional payment to PMP increase. For m-payment service 
providers that would like to attract potential users, they are recommended to conduct promotional campaigns that emphasize the advantages of PMP over traditional payment. For example, quicker transactions, faster shopping, and a higher possibility of preventing virus diffusion are more convenient features, such as making transactions anytime and anywhere. Economic benefits, for example, monetary rewards, are also suggested to PMP service providers since monetary rewards serve as a significant factor in attracting potential users [75].

Second, PMP service providers should focus on PUF construct as the most significant factor in pull effects. For example, service providers can mobilize migrants to express how useful it is to use the services and share their experiences through social networking sites. This will enable potential users to recognize the utility of PMP. Additionally, service providers can simplify the usage process of PMP to enhance their usefulness perception. This may increase users' switching intention to PMP.

Furthermore, service providers should continuously develop new functions to gratify users' various needs. They can adopt advances in technology to enhance users' substitutability perceptions between traditional payment and PMP. For instance, service providers can integrate PMP with artificial intelligence (AI) to enable the PMP transaction to be completed via users' voices without a password or fingerprint. Service providers can also increase the identification degree of various cards, such as a wide range of bank cards and loyalty cards.

Finally, service providers are recommended to consider the role of perceived technical compatibility carefully. They should improve the compatibility of their services with users' mobile devices, including OSs and apps. Notably, users' perception about technical compatibility depends not only on the compatibility with their mobile devices but also highly relevant to the compatibility with merchants' card-readers. Therefore, to provide a satisfactory transaction experience, service providers should optimize their services to be compatible well with card-readers on the merchant side. Furthermore, though perceived risk had minimal effect on switching intention, there is a need for service providers to regularly upgrade their service technologies to advance the degree of security and decrease the possibility of being hacked. For example, service providers can alleviate users' risk perception by delivering a message after upgrading the services and ensure that they can safeguard users' personal information and financial security.

\subsection{Limitations}

The current research has several limitations. First, the current research did not consider switching behavior as the main outcome. It is not essential for users to thoroughly terminate the usage of traditional payment after migrating to PMP. A gradual migration period may exist during which they try to accept the alternative services while concurrently use the incumbent service [76,77]. Second, samples of the current research were restricted to South Korea. The findings may be different across different countries and different cultures. Cross-cultural studies are supposed to gain a better understanding of switching behaviors. Third, future studies interested in perceived substitutability and perceived technical compatibility constructs can further improve their knowledge. For example, future studies may develop new items in detail, such as focusing on describing the specific functions to satisfy users' particular needs, the compatibility between users and merchants. Last but not least, the current study focused on the migration stream, and as such, we do not consider counter-stream. Since switching is a complex phenomenon, users may return to the incumbent services to re-evaluate the balance of positive and negative factors of both incumbent and alternative services [16] (p. 55). Future studies are suggested to conduct a counter-stream study that will likely provide new insights into literature and practice.

Author Contributions: Conceptualization, H.L.M. and Y.C.L.; methodology H.L.M. and Y.C.L.; software, H.L.M.; validation, H.L.M. and Y.C.L.; formal analysis, H.L.M; data curation, H.L.M.; writing-original draft preparation, H.L.M.; writing-review and editing, H.L.M. and Y.C.L.; All authors have read and agreed to the published version of the manuscript. 
Funding: This research received no external funding.

Institutional Review Board Statement: Not applicable.

Informed Consent Statement: Not applicable.

Data Availability Statement: Not applicable.

Conflicts of Interest: The authors declare no conflict of interest.

Appendix A. Questionnaire.

\begin{tabular}{|c|c|c|c|c|}
\hline Construct & Indicators & Mean & Items & Sources \\
\hline \multirow{5}{*}{$\begin{array}{l}\text { Dissatisfac- } \\
\text { tion }\end{array}$} & \multicolumn{3}{|c|}{$\begin{array}{l}\text { How do you feel about your overall experience using traditional payment (e.g., cash, } \\
\text { bank cards) in a physical store? }\end{array}$} & \multirow{5}{*}{ [37] } \\
\hline & DIS1 & 3.51 & Satisfied & \\
\hline & DIS2 & 3.65 & Pleased & \\
\hline & DIS3 & 3.66 & Contented & \\
\hline & DIS4 & 3.75 & Delighted & \\
\hline \multirow{3}{*}{$\begin{array}{l}\text { Perceived } \\
\text { technical } \\
\text { compatibility }\end{array}$} & TCP1 & 5.16 & $\begin{array}{l}\text { The proximity mobile payment (e.g., Samsung Pay, Kakao } \\
\text { Pay) is compatible with my mobile devices hardware (e.g. } \\
\text { NFC, Bluetooth, camera). }\end{array}$ & \multirow{3}{*}{ [58] } \\
\hline & TCP2 & 5.27 & $\begin{array}{l}\text { The proximity mobile payment is compatible with my mobile } \\
\text { devices' legacy operational system. }\end{array}$ & \\
\hline & TCP3 & 5.49 & $\begin{array}{l}\text { The proximity mobile payment is compatible with my mobile } \\
\text { devices' applications. }\end{array}$ & \\
\hline \multirow{3}{*}{$\begin{array}{l}\text { Perceived } \\
\text { risk }\end{array}$} & PER1 & 4.38 & $\begin{array}{l}\text { I am worried that my data stored in my proximity mobile } \\
\text { payment will be used by the proximity mobile payment } \\
\text { provider without my authorization. }\end{array}$ & \multirow{3}{*}[58,62,83]{} \\
\hline & PER2 & 4.28 & $\begin{array}{l}\text { I am worried that my data stored in my proximity mobile } \\
\text { payment will be sold to some profit-seeking organizations } \\
\text { without my authorization. }\end{array}$ & \\
\hline & PER3 & 2.97 & $\begin{array}{l}\text { I think it is risky to use the proximity mobile payment } \\
\text { platform for transactions in a physical store. }\end{array}$ & \\
\hline
\end{tabular}

Appendix A. Cont.

\begin{tabular}{|c|c|c|c|c|}
\hline Construct & Indicators & Mean & Items & Sources \\
\hline & PER4 & 2.72 & $\begin{array}{l}\text { I think there will be monetary losses when using the proximity } \\
\text { mobile payment for paying in a physical store. }\end{array}$ & \\
\hline & PER5 & 3.87 & $\begin{array}{l}\text { I am worried that my proximity mobile payment provider does } \\
\text { not implement security measures to protect my stored data. }\end{array}$ & \\
\hline & PER6 & 3.69 & $\begin{array}{l}\text { I am worried that my proximity mobile payment provider does } \\
\text { not have effective mechanisms to ensure that my transaction } \\
\text { data are protected from being altered or destroyed accidentally } \\
\text { during transaction in a physical store. }\end{array}$ & \\
\hline \multirow{3}{*}{$\begin{array}{l}\text { Perceived } \\
\text { substitutabil- } \\
\quad \text { ity }\end{array}$} & PSS1 & 4.49 & $\begin{array}{l}\text { In a physical store, traditional payment offers the same services } \\
\text { as the proximity mobile payment. }\end{array}$ & \multirow{3}{*}{ [84] } \\
\hline & PSS2 & 4.22 & $\begin{array}{l}\text { In a physical store, traditional payment offers services in the } \\
\text { same way as the proximity mobile payment. }\end{array}$ & \\
\hline & PSS3 & 4.26 & $\begin{array}{l}\text { In a physical store, traditional payment satisfies the same needs } \\
\text { as the proximity mobile payment. }\end{array}$ & \\
\hline $\begin{array}{l}\text { Perceived } \\
\text { usefulness }\end{array}$ & PUF1 & 5.21 & $\begin{array}{l}\text { Proximity mobile payment allows to do my transactions more } \\
\text { quickly in a physical store. }\end{array}$ & [28] \\
\hline
\end{tabular}




\begin{tabular}{|c|c|c|c|c|}
\hline & PUF2 & 5.31 & $\begin{array}{l}\text { The use of the proximity mobile payment would improve my } \\
\text { effectiveness in conducting my transactions in a physical store. }\end{array}$ & \\
\hline & PUF3 & 5.46 & $\begin{array}{l}\text { Using proximity mobile payment would make the handing of } \\
\text { transactions easier in a physical store. }\end{array}$ & \\
\hline & PUF4 & 5.47 & Overall, proximity mobile payment is useful. & \\
\hline \multirow{4}{*}{$\begin{array}{l}\text { Perceived } \\
\text { ease of use }\end{array}$} & PEU1 & 5.59 & $\begin{array}{l}\text { Learning to use proximity mobile payment in a physical store } \\
\text { would be easy for me. }\end{array}$ & \multirow{4}{*}[28,85]{} \\
\hline & PEU2 & 5.70 & $\begin{array}{l}\text { Using proximity mobile payment in a physical store is not } \\
\text { challenging. }\end{array}$ & \\
\hline & PEU3 & 5.56 & $\begin{array}{l}\text { It would be easy to follow all the steps to use proximity mobile } \\
\text { payment in a physical store. }\end{array}$ & \\
\hline & PEU4 & 5.66 & Overall, I find that proximity mobile payment to be easy to use. & \\
\hline \multirow{5}{*}{ Self-efficacy } & SEF1 & 5.33 & $\begin{array}{l}\text { If there was nobody tell what to do, I would be able to complete } \\
\text { my payment using proximity mobile payment in a physical } \\
\text { store. }\end{array}$ & \multirow{5}{*}[19]{} \\
\hline & SEF2 & 5.52 & $\begin{array}{l}\text { If I had only the proximity mobile payment manuals for } \\
\text { reference, I would be able to make a transaction using it in a } \\
\text { physical store. }\end{array}$ & \\
\hline & SEF3 & 5.51 & $\begin{array}{l}\text { If I could call someone for help when I need, I could complete } \\
\text { my payment using proximity mobile payment in a physical } \\
\text { store. }\end{array}$ & \\
\hline & SEF4 & 5.58 & $\begin{array}{l}\text { If I had used a similar proximity mobile payment in the past, I } \\
\text { could complete my payment using it in a physical store. }\end{array}$ & \\
\hline & SEF5 & 5.59 & $\begin{array}{l}\text { If someone showed me how to use it, I could complete my } \\
\text { payment using proximity mobile payment in a physical store. }\end{array}$ & \\
\hline \multirow{3}{*}{$\begin{array}{l}\text { Switching in- } \\
\text { tention }\end{array}$} & SWI1 & 5.21 & $\begin{array}{l}\text { Please rate your possibility to switch from traditional payment } \\
\text { to proximity mobile payment in a physical store in the near } \\
\text { future. }(1=\text { Improbable... } 7=\text { Probable })\end{array}$ & \multirow{3}{*}{$\begin{array}{l}{[17,18,} \\
78]\end{array}$} \\
\hline & SWI2 & 5.54 & $\begin{array}{l}\text { The possibility of my switching to proximity mobile payment in } \\
\text { a physical store is high in the near future. }\end{array}$ & \\
\hline & SWI3 & 5.40 & $\begin{array}{l}\text { I intend to increase time on proximity mobile payment in a } \\
\text { physical store in the near future. }\end{array}$ & \\
\hline
\end{tabular}

Appendix B. Non-response bias analysis.

\begin{tabular}{lcccccc}
\hline & $\begin{array}{c}\text { The first } \\
\text { 25 percent } \\
\text { responses } \\
(\mathbf{n}=\mathbf{7 8})\end{array}$ & $\begin{array}{c}\text { The final } \\
\mathbf{2 5} \\
\text { percent } \\
\text { responses } \\
\mathbf{( n = 7 8 )}\end{array}$ & $\begin{array}{c}\text { Significance } \\
\text { (p-value) }\end{array}$ & $\begin{array}{c}\text { Valid } \\
\text { responses } \\
(\mathbf{n}=\mathbf{3 1 1})\end{array}$ & $\begin{array}{c}\text { Invalid } \\
\text { responses } \\
\mathbf{( n = 6 1 )}\end{array}$ & $\begin{array}{c}\text { Significance } \\
\text { (p-value) }\end{array}$ \\
\hline DIS & 3.679 & 3.599 & 0.732 & 3.644 & 3.462 & 0.365 \\
\hline TCP & 5.256 & 5.145 & 0.611 & 5.308 & 5.044 & 0.156 \\
\hline PER & 3.823 & 3.899 & 0.692 & 3.654 & 3.809 & 0.169 \\
\hline PSS & 4.389 & 4.385 & 0.986 & 4.324 & 4.098 & 0.265 \\
\hline PUF & 5.366 & 5.282 & 0.673 & 5.363 & 5.102 & 0.129 \\
\hline PEU & 5.696 & 5.429 & 0.163 & 5.629 & 5.365 & 0.157 \\
\hline SEF & 5.474 & 5.462 & 0.947 & 5.507 & 5.219 & 0.094 \\
\hline SWI & 5.466 & 5.325 & 0.549 & 5.414 & 5.109 & 0.185 \\
\hline NOte: & & & & & \\
\hline
\end{tabular}

Note: DIS = Dissatisfaction; TCP = Perceived technical compatibility; PER = Perceived risk; PSS = Perceived substitutability $;$ PUF = Perceived usefulness; PEU = Perceived ease of use; $\mathrm{SEF}=$ Self-efficacy; SWI $=$ Switching intention . 
Three methods were adopted to assess CMB. Harman's single-factor [87] was adopted first. Our analysis generated eight factors and the largest factor captured 33\% of the variance. Second, common method variable (CMV) method [88] was used. Appendix $\mathrm{C}$ shows that the average substantive factor loadings were 0.774 , whereas the average method-based factor loadings were 0.003. Finally, correlational marker variable method recommended by [89] was adopted. There should be no theoretical relationship with other scales for a marker variable. A proxy for method variance for marker variable is also available. Therefore, age, a demographic variable in the current research was selected as marker variable. This study adopted age to partial out the correlations caused by CMB. Appendix D indicates that before adjustment, the correlation between marker variable and dependent variable was not significant $(0.011, \mathrm{p}>0.05)$, and all independent variables were highly correlated with dependent variable. All significant correlations were still significant and no significant differences were found between adjusted and unadjusted correlations. These analyses suggested that $\mathrm{CMB}$ was not a concern to our data.

Appendix C. Common method bias tests.

\begin{tabular}{ccccc}
\hline Indicators & $\begin{array}{c}\text { Substantive } \\
\text { factor loading } \\
\mathbf{( R 1 )}\end{array}$ & $\mathbf{R 1}^{\mathbf{2}}$ & $\begin{array}{c}\text { Method factor } \\
\text { loadings (R2) }\end{array}$ & $\mathbf{R}^{\mathbf{2}}$ \\
\hline DIS1 & 0.867 & 0.751 & 0.009 & 0.000 \\
\hline DIS2 & 0.898 & 0.807 & 0.004 & 0.000 \\
\hline DIS3 & 0.925 & 0.856 & 0.006 & 0.000 \\
\hline DIS4 & 0.925 & 0.855 & -0.001 & 0.000 \\
\hline TCP1 & 0.920 & 0.846 & 0.049 & 0.002 \\
\hline TCP2 & 0.971 & 0.943 & 0.050 & 0.002 \\
\hline TCP3 & 0.807 & 0.651 & 0.060 & 0.004 \\
\hline PER1 & 0.927 & 0.859 & -0.021 & 0.000 \\
\hline PER2 & 0.914 & 0.836 & -0.027 & 0.001 \\
\hline PER3 & 0.617 & 0.381 & -0.051 & 0.003 \\
\hline PER4 & 0.562 & 0.316 & -0.053 & 0.003 \\
\hline PER5 & 0.880 & 0.775 & -0.031 & 0.001 \\
\hline PER6 & 0.857 & 0.734 & -0.036 & 0.001 \\
\hline
\end{tabular}

Appendix C. Cont.

\begin{tabular}{ccccc}
\hline Indicators & $\begin{array}{c}\text { Substantive factor } \\
\text { loading (R1) }\end{array}$ & $\mathbf{R 1}^{2}$ & $\begin{array}{c}\text { Method factor } \\
\text { loadings (R2) }\end{array}$ & R2 $^{2}$ \\
\hline PSS1 & 0.879 & 0.772 & 0.027 & 0.001 \\
\hline PSS2 & 0.877 & 0.769 & 0.030 & 0.001 \\
\hline PSS3 & 0.825 & 0.681 & 0.028 & 0.001 \\
\hline PUF1 & 0.953 & 0.909 & 0.061 & 0.004 \\
\hline PUF2 & 0.914 & 0.835 & 0.067 & 0.005 \\
\hline PUF3 & 0.884 & 0.782 & 0.067 & 0.004 \\
\hline PUF4 & 0.790 & 0.624 & 0.068 & 0.005 \\
\hline PEU1 & 0.876 & 0.767 & 0.070 & 0.005 \\
\hline PEU2 & 0.907 & 0.822 & 0.073 & 0.005 \\
\hline PEU3 & 0.897 & 0.804 & 0.069 & 0.005 \\
\hline PEU4 & 0.936 & 0.875 & 0.066 & 0.004 \\
\hline SEF1 & 0.779 & 0.607 & 0.069 & 0.005 \\
\hline SEF2 & 0.875 & 0.766 & 0.073 & 0.005 \\
\hline SEF3 & 0.938 & 0.880 & 0.071 & 0.005 \\
\hline SEF4 & 0.868 & 0.753 & 0.072 & 0.005
\end{tabular}




\begin{tabular}{ccccc} 
SEF5 & 0.932 & 0.868 & 0.070 & 0.005 \\
\hline SWI1 & 0.949 & 0.901 & 0.066 & 0.004 \\
\hline SWI2 & 0.934 & 0.873 & 0.071 & 0.005 \\
\hline SWI3 & 0.930 & 0.865 & 0.071 & 0.005 \\
\hline Average & 0.875 & 0.774 & 0.036 & 0.003 \\
\hline
\end{tabular}

Note: DIS = Dissatisfaction; TCP = Perceived technical compatibility; PER = Perceived risk; PSS = Perceived substitutability; PUF = Perceived usefulness; PEU = Perceived ease of use; SEF $=$ Self-efficacy; SWI $=$ Switching intention .

Appendix D. Correlation coefficients between marker variable and main factors.

\begin{tabular}{|c|c|c|c|c|c|c|c|c|c|}
\hline & DIS & TPC & PER & PSS & PUF & PEU & SEF & Age & SWI \\
\hline DIS & 1 & & & & & & & & \\
\hline TCP & -0.025 & 1 & & & & & & & \\
\hline PER & $-0.185^{* *}$ & $-0.178^{* *}$ & 1 & & & & & & \\
\hline PSS & $-0.282^{* *}$ & $0.155^{* *}$ & $-0.113^{*}$ & 1 & & & & & \\
\hline PUF & 0.022 & $0.416^{* *}$ & $-0.229^{* *}$ & $0.221^{* *}$ & 1 & & & & \\
\hline PEU & -0.061 & $0.521^{* *}$ & $-0.151^{* *}$ & $0.210^{* *}$ & $0.584^{* *}$ & 1 & & & \\
\hline SEF & -0.025 & $0.411^{* *}$ & $-0.247^{* *}$ & $0.353^{* *}$ & $0.576^{* *}$ & $0.695^{* *}$ & 1 & & \\
\hline Age & 0.069 & 0.057 & -0.017 & -0.096 & 0.040 & $-0.111^{*}$ & 0.032 & 1 & \\
\hline \multirow{2}{*}{ SWI } & $0.172^{* *}$ & $0.449^{* *}$ & $-0.309^{* *}$ & $0.254^{* *}$ & $0.656^{* *}$ & $0.519^{* *}$ & $0.547^{* *}$ & 0.011 & 1 \\
\hline & 0.163 & 0.443 & -0.324 & 0.246 & 0.652 & 0.514 & 0.542 & 0 & \\
\hline
\end{tabular}

Note: The last line is the correlation corrected for method bias. DIS = Dissatisfaction; TCP = Perceived technical compatibility; PER = Perceived risk; PSS = Perceived substitutability; PUF = Perceived usefulness; PEU = Perceived ease of use; $\mathrm{SEF}=$ Self-efficacy; SWI $=$ Switching intention.

\section{References}

1. Dahlberg, T.; Mallat, N.; Ondrus, J.; Zmijewska, A. Past, present and future of mobile payments research: a literature review. Electron. Commer. Res. Appl. 2008, 7, 165-181.

2. Oliveira, T.; Thomas, M.; Baptista, G.; Campos, F. Mobile payment: understanding the determinants of customer adoption and intention to recommend the technology. Comput. Hum. Behav. 2016, 61, 404-414.

3. Zhou, T. An empirical examination of continuance intention of mobile payment services. Decis. Support Syst. 2013, 54, 1085-1091.

4. Gerpott, T.J.; Meinert, P. Who signs up for NFC mobile payment services? Mobile network operator subscribers in Germany. Electron. Commer. Res. Appl. 2017, 23, 1-13.

5. Karnouskos, S.; Fokus, F. Mobile payment: a journey through existing procedures and standardization initiatives. IEEE Commun. Surv. Tutor. 2004, 6, 44-66.

6. McKinsey \& Company. The 2020 McKinsey Global Payments Report. 2020. Available at: https://www.mckinsey.com/ /media/McKinsey/Industries/Financial\%20Services/Our\%20Insights/Accelerating\%20winds\%20of\%20change\%20in\%20global\%20payments/2020-McKinsey-Global-Payments-Report-vF.pdf

7. Statista. Number of proximity mobile payment transaction users worldwide from 2018 to 2023. 2019. Available at: https://www.statista.com/statistics/557959/global-mobile-proximity-payment-users/

8. Statista. Proximity mobile payment usage penetration in selected countries in 2019. 2019. Available at: https://www.statista.com/statistics/244501/share-of-mobile-phone-users-accessing-proximity-mobile-payments-country/

9. The Korea Herald. One-third of Korea's smartphone users to make mobile payments in 2018. 2018. Available at http://www.koreaherald.com/view.php?ud=20180116000867

10. Johnson, V.L.; Kiser, A.; Washington, R.; Torres, R. Limitations to the rapid adoption of M-payment services: understanding the impact of privacy risk on M-payment services. Comput. Hum. Behav. 2018, 79, 111-122.

11. Yang, S.; Lu, Y.; Gupta, S.; Cao, Y.; Zhang, R. Mobile payment services adoption across time: an empirical study of the effects of behavioral beliefs, social influence, and personal traits. Comput. Hum. Behav. 2012, 28, 129-142.

12. Amoroso, D.L.; Chen, Y.A.N. Constructs affecting continuance intention in consumers with mobile financial apps: a dual factor approach. J. Inf. Technol. Manage. 2017, 28, 1-24.

13. Chen, X.; Li, S. Understanding continuance intention of mobile payment services: an empirical study. J. Comput. Inf. Syst. 2017, 57, 287-298.

14. Ye, C.; Seo, D.; Desouza, K.C.; Sangareddy, S.P.; Jha, S. Influences of IT substitutes and users experience on post-adoption user switching: an empirical investigation. J. Am. Soc. Inf. Sci. Tec. 2008, 59, 2115-2132.

15. Ye, C.; Potter, R. The role of habit in post-adoption switching of personal information technologies: an empirical investigation. 
Commun. Assoc. Inf. Syst. 2011, 28, 1-28.

16. Lee, E.S. A theory of migration. Demography. 1966, 3, 47-57.

17. Bansal, H.S.; Taylor, S.F.; James, Y.S. "Migrating" to new service provides: toward a unifying framework of consumers' switching behaviors. J. Acad. Mark. Sci. 2005, 33, 96-115.

18. Wu, K.; Vassileva, J.; Zhao, Y. Understanding users' intention to switch personal cloud storage services: evidence from the Chinese market. Comput. Hum. Behav. 2017, 68, 300-314.

19. Peng, X.; Zhao, Y.C.; Zhu, Q. Investigating users switching intention for mobile instant messaging application: taking WeChat as an example. Comput. Hum. Behav. 2016, 64, 206-216.

20. Ravenstein, E.G. The laws of migration. J. Stat. Soc. Lond. 1885, 48, 167-235.

21. Jackson, J.A. Migration; In Aspects of Modern Sociology: Social Processes. London and New York: Longman, 1986.

22. Xu, Y.C.; Yang, Y.; Cheng, Z.; Lim, J. Retaining and attracting users in social networking services: an empirical investigation of cyber migration. J. Strateg. Inf. Syst. 2014, 23, 239-253.

23. Li, C.Y.; Ku, Y.C. The power of a thumbs-up: Will e-commerce switch to social commerce? Inf. Manage. 2018, 55, 340-357.

24. Bhattacherjee, A.; Park, S.C. Why end-users move to the cloud: a migration-theoretic analysis. Eur. J. Inf. Syst. 2014, 23, 357-372.

25. Lin, C.A. Audience fragmentation in a competitive video marketplace. J. Advert. Res. 1994, 34, 30-39.

26. Cha, J. Predictors of television and online video platform use: a coexistence model of old and new video platforms. Telematics Inform. 2013, 30, 296-310.

27. Ferguson, D.A.; Perse, E.M. The World Wide Web as is functional alternative to television. J. Broadcast Electron. Media. 2000, 44, 155-174.

28. Davis, F.D. Perceived usefulness, perceived ease of use, and users acceptance of information technology. MIS Q. 1989, 13, 319340.

29. Fishbein, M.; Ajzen, I. Belief, Attitude, Intention and Behavior: An Introduction to Theory and Research; Addison-Wesley, Reading, MA, 1975.

30. Rogers, E.M. Diffusion of Innovations, fourth ed.; Free Press, New York, 1995.

31. Venkatesh, V.; Morris, M.G.; Davis, G.B.; Davis, F.D. User acceptance of information technology: toward a unified view. MIS Q. 2003, 27, 425-478.

32. Tan, G.W.H.; Ooi, K.B.; Chong, S.C.; Hew, T.S. NFC mobile credit card: the next frontier of mobile payment? Telematics Inform. 2014, 31, 292-307.

33. Hassan, H.E.; Wood, V.R. Does country culture influence consumers' perceptions toward mobile banking? A comparison between Egypt and the United States. Telematics Inform. 2020, 46, 1-14.

34. de Luna, I.R.; Liébana-Cabanillas, F.; Sánchez-Fernández, J.; Muñoz-Leiva, F. Mobile payment is not all the same: the adoption of mobile payment systems depending on the technology applied. Technol. Forecast Soc. Change. 2019, 146, 931-944.

35. Kim, C.; Mirusmonov, M.; Lee, I. An empirical examination of factors influencing the intention to use mobile payment. Comput. Hum. Behav. 2010, 26, 310-322.

36. Lu, Y.; Yang, S.; Chau, P.Y.; Cao, Y. Dynamics between the trust transfer process and intention to use mobile payment services: a cross-environment perspective. Inf. Manage. 2011, 48, 393-403.

37. Bhattacherjee, A. Understanding information systems continuance: an expectation-confirmation model. MIS Q. 2001, 25, 351370.

38. Li, C.Y. Fang, Y.H. Predicting continuance intention toward mobile branded apps through satisfaction and attachment. Telematics Inform. 2019, 43, 1-13.

39. Park, E. User acceptance of smart wearable devices: an expectation-confirmation model approach. Telematics Inform. 2020, 47, 111.

40. Zhou, T. An empirical examination of users' post-adoption behavior of mobile services. Behav. Inf. Technol. 2011, 30, 241-250.

41. Parthasarathy, M.; Bhattacherjee, A. Understanding post-adoption behavior in the context of online services. Inf. Syst. Res. 1998, 9, 362-379.

42. Wolman, D. The End of Money: Counterfeiters, Preachers, Techies, Dreamers-and the Coming Cashless Society; Hachette UK, 2003.

43. Sadeh, N. M-Commerce Technologies, Services, and Business Models; John Wiley \& Sons, New York, 2003.

44. Chang, I.C.; Liu, C.C.; Chen, K. The push, pull and mooring effects in virtual migration for social networking sites. Inf. Syst. J. 2014, 24, 323-346.

45. Cha, J.; Chan-Olmsted, S.M. Substitutability between online video platforms and television. J. Mass Commun. Q. 2012, 89, 261278.

46. Perse, E.M.; Courtright, J.A. Normative images of communication media mass and interpersonal channels in the new media environment: mass and interpersonal channels in the new media environment. Hum. Commun. Res. 1993, 19, 485-503.

47. Schierholz, R.; Laukkanen, T. Internet vs mobile banking: comparing customer value perceptions. Bus. Process Manag. J. 2007, 13, 788-797.

48. Teo, A.C.; Tan, G.W.H.; Ooi, K.B.; Hew, T.S.; Yew, K.T. The effects of convenience and speed in m-payment. Ind. Manage. Data Syst. 2015, 115, 311-331.

49. Li, C.Y. Consumer behavior in switching between membership cards and mobile applications: the case of Starbucks. Comput. Hum. Behav. 2018, 84, 171-184.

50. Brown, S.A.; Venkatesh, V. Model of adoption of technology in households: a baseline model test and extension incorporating household life cycle. MIS Q. 2005, 29, 399-426.

51. Hsieh, J.K.; Hsieh, Y.C.; Chiu, H.C.; Feng, Y.C. Post-adoption switching behavior for online service substitutes: A perspective of 
the push-pull-mooring framework. Comput. Hum. Behav. 2012, 28, 1912-1920.

52. Hassan, H.E.; Wood, V.R. Does country culture influence consumers' perceptions toward mobile banking? A comparison between Egypt and the United States. Telematics Inform. 2020, 46, 1-14.

53. Raza, S.A.; Umer, A.; Shah, N. New determinants of ease of use and perceived usefulness for mobile banking adoption. Int. J. Electron. Cust. Relatsh. Manage. 2017, 11, 44-65.

54. Verkijika, S.F. Factors influencing the adoption of mobile commerce applications in Cameroon. Telematics Inform. 2018, 35, 16651674.

55. Moon, B. Paradigms in migration research: exploring 'moorings' as a schema. Prog. Hum. Geogr. 1995, 19, 504-524.

56. Karahanna, E.; Agarwal, R.; Angst, C.M. Reconceptualizing compatibility beliefs in technology acceptance research. MIS Q. 2006, 30, 781-804.

57. Vallerand, R.J. Toward a hierarchical model of intrinsic and extrinsic motivation. Adv. Exp. Soc. Psychol. 1997, 29, 271-360.

58. Cheng, S.; Lee, S.J.; Choi, B. An empirical investigation of users' voluntary switching intention for mobile personal cloud storage services based on the push-pull-mooring framework. Comput. Hum. Behav. 2019, 92, 198-215.

59. Mallat, N. Exploring consumer adoption of mobile payments-A qualitative study. J. Strateg. Inf. Syst. 2007, 16, 413-432.

60. Tornatzky, L.G.; Klein, K.J. Innovation characteristics and innovation adoption-implementation: a meta-analysis of findings. IEEE Trans. Eng. Manage. 1982, 29, 28-45.

61. Featherman, M.S.; Pavlou, P.A. Predicting e-services adoption: a perceived risk facets perspective. Int. J. Hum. Comput. Stud. 2003, 59, 451-474.

62. McKnight, D.H.; Choudhury, V.; Kacmar, C. The impact of initial consumer trust on intentions to transact with a web site: a trust building model. J. Strateg. Inf. Syst. 2002, 11, 297-323.

63. Chang, Y.F.; Chen, C.S.; Zhou, H. Smart phone for mobile commerce. Comput. Stand. Interfaces. 2009, 31, 740-747.

64. Slade, E.L.; Williams, M.D.; Dwivedi, Y.K. Mobile payment adoption: classification and review of the extant literature. Mark. Rev. 2013, 13, 167-190.

65. Kim, M.; Kim, S.; Kim, J. Can mobile and biometric payments replace cards in the Korean offline payments market? Consumer preference analysis for payment systems using a discrete choice model. Telematics Inform. 2019, 38, 46-58.

66. Ajzen, I. The theory of planned behavior. Organ. Behav. Hum. Decis. Process. 1991, 50, 179-211.

67. Ajzen, I. Perceived behavioral control, self-efficacy, locus of control, and the theory of planned behavior. J. Appl. Soc. Psychol. 2002, 32, 665-683.

68. Bandura, A. Self-efficacy mechanism in human agency. Am. Psychol. 1982, 37, 122-147.

69. Armstrong, J.S.; Overton, T.S. Estimating non-response bias in mail surveys. J. Mark. Res. 1977, 14, $396-402$.

70. Xu, F.; Luo, X.R.; Hsu, C. Anger or fear? Effects of discrete emotion on employee's computer-related deviant behavior. Inf. Manage. 2020, 57, 1-13.

71. Fornell, C.; Larcker, D.F. Evaluating structural equation models with unobservable variables and measurement error. J. Mark. Res. 1981, 18, 39-50.

72. Lai, J.Y.; Wang, J. Switching attitudes of Taiwanese middle-aged and elderly patients toward cloud healthcare services: an exploratory study. Technol. Forecast Soc. Change. 2015, 92, 155-167.

73. Slade, E.; Williams, M.; Dwivedi, Y.; Piercy, N. Exploring consumer adoption of proximity mobile payments. J. Strateg. Mark. 2015, 23, 209-223.

74. Koenig-Lewis, N.; Marquet, M.; Palmer, A.; Zhao, A.L. Enjoyment and social influence: predicting mobile payment adoption. Serv. Ind. J. 2015, 35, 537-554.

75. Wang, L.; Luo, X.R.; Yang, X.; Qiao, Z. Easy come or easy go? Empirical evidence on switching behaviors in mobile payment applications. Inf. Manage. 2019, 56, 1-13.

76. Chang, I.C.; Liu, C.C.; Chen, K. The push, pull and mooring effects in virtual migration for social networking sites. Inf. Syst. J. 2014, 24, 323-346.

77. Sun, Y.; Liu, D.; Chen, S.; Wu, X.; Shen, X.L.; Zhang, X. Understanding users' switching behavior of mobile instant messaging applications: an empirical study from the perspective of push-pull-mooring framework. Comput. Hum. Behav. 2017, 75, 727-738.

78. Lai, J.Y.; Debbarma, S.; Ulhas, K.R. An empirical study of consumer switching behavior towards mobile shopping: a push-pullmooring model. Int. J. Mob. Commun. 2012, 10, 386-404.

79. Lin, T.C.; Huang, S.L. Understanding the determinants of consumers' switching intentions in a standards war. Int. J. Electron. Commer. 2014, 19, 163-189.

80. Tornatzky, L.G.; Klein, K.J. Innovation characteristics and innovation adoption-implementation: a meta-analysis of findings. IEEE Trans. Eng. Manage. 1982, 29, 28-45.

81. Harrington, S.J.; Ruppel, C.P. Telecommuting: a test of trust, competing values, and relative advantage. IEEE Trans. Prof. Commun. 1999, 42, 223-239.

82. van Rijnsoever, F.J.; van Hameren, D.; Walraven, P.F.; van Dijk, J.P. Interdependent technology attributes and the diffusion of consumer electronics. Telematics Inform. 2009, 26, 410-420.

83. Kim, D.J.; Steinfield, C.; Lai, Y.J. Revisiting the role of web assurance seals in business-to-consumer electronic commerce. Decis. Support Syst. 2008, 44, 1000-1015.

84. Featherman, M.S.; Pavlou, P.A. Predicting e-services adoption: a perceived risk facets perspective. Int. J. Hum. Comput. Stud. 2003, 59, 451-474.

85. Moore, G.C.; Benbasat, I.. Development of an instrument to measure the perceptions of adopting an information technology innovation. Inf. Syst. Res. 1991, 2, 192-222. 
86. Venkatesh, V.; Davis, F.D. A model of the antecedents of perceived ease of use: development and test. Decis. Sci. 1996, 27, 451481.

87. Podsakoff, P.M.; MacKenzie, S.B.; Lee, J.Y.; Podsakoff, N.P. Common method biases in behavioral research: a critical review of the literature and recommended remedies. J. Appl. Psychol. 2003, 88, 879-903.

88. Liang, H.; Saraf, N.; Hu, Q.; Xue, Y. Assimilation of enterprise systems: the effect of institutional pressures and the mediating role of top management. MIS Q. 2007, 31, 59-87.

89. Lindell, M.K.; Whitney, D.J. Accounting for common method variance in cross-sectional research designs. J. Appl. Psychol. 2001, 86, 114-121.

90. Wei, M.F.; Luh, Y.H.; Huang, Y.H.; Chang, Y.C. Young generation's mobile payment adoption behavior: Analysis based on and extended UTAUT model. J. Theor. Appl. Electron. Commer. Res. 2021, 16, 618-637.

91. Fan, L.; Zhang, X.; Rai, L.; Du, Y. Mobile payment: The next frontier of payment systems? - An empirical study based on pushpull-mooring framework. J. Theor. Appl. Electron. Commer. Res. 2021, 16, 155-169. 